\title{
Colorimetric sensing of anions in aqueous solution using a charge neutral, cleft-like, amidothiourea receptor: tilting the balance between hydrogen bonding and deprotonation in anion recognition $\uparrow+$
}

\author{
Rebecca M. Duke, John E. O'Brien, Thomas McCabe and Thorfinnur Gunnlaugsson*
}

Received 6th May 2008, Accepted 17th September 2008

First published as an Advance Article on the web 3rd October 2008

DOI: 10.1039/b807579d

The design, synthesis and physical evaluation of 1 , a visible colorimetric 'naked eye' pyridyl based bis-amidothiourea sensor for anions, is described. This charge neutral sensor gives rise to significant changes in the absorption spectra upon interactions with several important biological anions such as AMP and ADP in $4: 1 \mathrm{DMSO}-\mathrm{H}_{2} \mathrm{O}$ solution, while ATP was not detected. These colorimetric changes are due to the formation, or the combination of hydrogen bonding complexes and/or deprotonation between these anions and 1.

Sensing of anions in both organic and aqueous solutions has become an active field of research within supramolecular chemistry. ${ }^{1-3}$ Such sensing has been achieved using both fluorescent ${ }^{4,5}$ and metal based luminescence ${ }^{6}$ chemosensors. Inspired by the work of Gale et al., ${ }^{7}$ Crabtree et al. ${ }^{8}$ and $\mathrm{He}$ et al., ${ }^{9}$ all of whom have used amido or urea based 2,6dicarboxyamidopyridine receptors for anion recognition or sensing, we decided on incorporating nitro-phenyl based amido(thio) urea $^{10}$ functionalities into this structure. This gave the dinitro derivative 1 , which was characterized using various techniques, including X-ray crystallography. Sensor $\mathbf{1}$ was shown to detect various anions in both DMSO and 4:1 DMSO- $\mathrm{H}_{2} \mathrm{O}$ solutions, where the anion recognition was visible to the naked eye, ${ }^{11}$ a consequence of significant colorimetric changes occurring in the absorption spectra, with $\lambda_{\max }$ being red shifted by almost $100 \mathrm{~nm}$. Most importantly, $\mathbf{1}$ was able to clearly distinguish between AMP over ADP or ATP in aqueous solutions. This is, to the best of our knowledge, the first example of such a charge neutral colorimetric anion sensor that detects phosphate anions in aqueous solution.

The synthesis of 1 is shown in Scheme 1.2,6-Pyridinedicarboxylic acid was first converted to its corresponding di-methyl ester $\mathbf{2}$, followed by reacting it in refluxing $\mathrm{MeOH}$ with hydrazine monohydrate. This gave 2,6-pyridinedicarboxylic acid, dihydrazide, $\mathbf{3}$, which was subsequently reacted with 4-nitrophenylisothiocyanate, 4, in dry $\mathrm{CH}_{3} \mathrm{CN}$ to give $\mathbf{1}$ (upon precipitation) as a pale yellow solid in $98 \%$ yield, after washing with $\mathrm{CH}_{3} \mathrm{CN}$. The ${ }^{1} \mathrm{H}$ NMR $\left(600 \mathrm{MHz}\right.$, DMSO- $\left.d_{6}\right)$ demonstrated that 1 had the expected $\mathrm{C}_{2}$ symmetry with the presence of three broad and major $\mathrm{N}-\mathrm{H}$

School of Chemistry, Centre for Synthesis and Chemical Biology, Trinity College Dublin, Dublin 2, Ireland. E-mail: gunnlaut@tcd.ie; Fax:00353 1671 2826; Tel: 0035318963459

$\dagger$ In loving memory of Noeleen Duke.

\$Electronic supplementary information (ESI) available: Synthesis, Fig. S1-S20. CCDC reference number 649247. For ESI and crystallographic data in CIF or other electronic format see DOI: 10.1039/b807579d
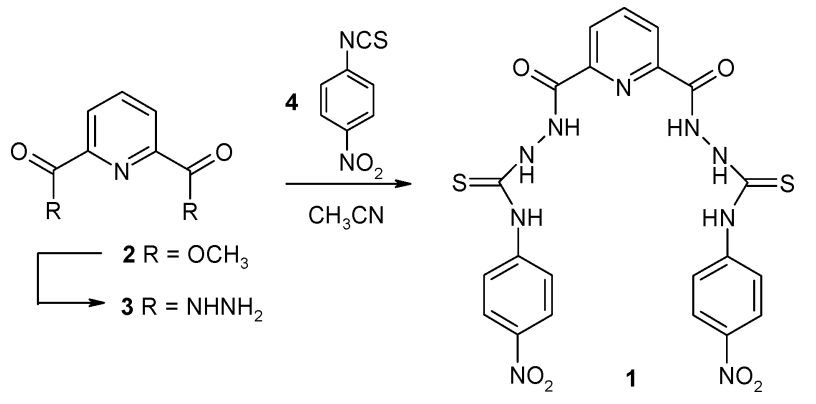

Scheme 1 Synthesis of the colorimetric anion sensor 1.

resonances, occurring at $11.30,10.37$ and $10.20 \mathrm{ppm}$ (shown as part of Fig. 6), respectively. These were assigned to the amide and the two urea protons on each 'arm' using ${ }^{1} \mathrm{H}-{ }^{1} \mathrm{H}$ and ${ }^{15} \mathrm{~N}-{ }^{1} \mathrm{H}$ COSY NMR (600 MHz, DMSO- $d_{6}$, ESI $\$$ ). However, there were also a minor set of signals in the spectra that were assigned to $\mathrm{N}-\mathrm{H}$ protons. These we assigned to a rotamer of $\mathbf{1}$, which exists at room temperature, as upon heating, a single species was observed. In contrast, the ${ }^{1} \mathrm{H}$ NMR of 1 in DMF- $d_{7}$ at room temperature only showed a singe rotamer in solution (see ESI + ).

We were also able to grow crystals of 1 suitable for X-ray crystallographic analysis from both DMSO and DMSO- $d_{6}$ solutions, Fig. 1. The combination of H-bonding and $\pi-\pi$ stacking also gave rise to an elaborate $3 \mathrm{D}$ network that was perforated with ordered DMSO solvent filled channels. $\uparrow$ On both occasions, the unit cell obtained was the same; giving the structure shown in Fig. 1. Here, the asymmetric unit contained two molecules of 1 and six DMSO molecules, all of which were hydrogen bonding directly to the $\mathrm{N}-\mathrm{H}$ protons within the amidothiourea receptor. It was also clear from the structure that the thiourea protons of

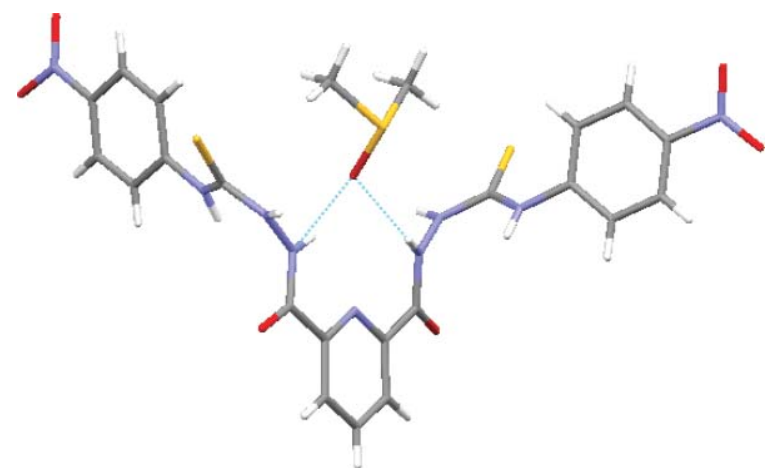

Fig. 1 The X-ray crystal structure of $\mathbf{1}$, obtained after recrystallisation from DMSO solution. The asymmetric unit contained a dimer of $\mathbf{1}$ and six DMSO molecules. Only one of these is shown above within the cleft. 
the two receptor moieties in $\mathbf{1}$ occupy an anti-conformation, but we had previously observed such geometry in amido-urea based colorimetric sensors. ${ }^{11 b}$

The spectroscopic investigation of $1\left(1 \times 10^{-5} \mathrm{M}\right)$ was first carried out in DMSO, which showed a broad absorption band centred at ca. $348 \mathrm{~nm}\left(\varepsilon=21270 \mathrm{M}^{-1} \mathrm{~cm}^{-1}\right)$ and a shoulder at a shorter wavelength at $c a .290 \mathrm{~nm}$. Upon titration with anions such as $\mathrm{AcO}^{-}$and $\mathrm{H}_{2} \mathrm{PO}_{4}{ }^{-}, \mathrm{HP}_{2} \mathrm{O}_{7}{ }^{3-}$ and $\mathrm{F}^{-}$(as their tetrabutylammonium, TBA, salts), a new band began to develop at a longer wavelength, centred at ca. $420 \mathrm{~nm}$, tailing into $560 \mathrm{~nm}$, as demonstrated for pyrophosphate in Fig. 2 (see ESI, Fig. S6, for other anions These are not unexpected results, and demonstrate that the anion is coordinating to the receptor (most likely) within the $\operatorname{cleft}^{12}$ of the sensor, which is in conjugation with the $p$-nitrophenyl group. This gives rise to enhanced internal charge transfer (ICT) character for this system and subsequently shifts the spectra to a longer wavelength. Most importantly, at such low concentration, these changes were clearly visible to the naked eye where the solution changes from colourless to yellow. ${ }^{13}$ In contrast to these results, titrations using $\mathrm{Cl}^{-}$only gave rise to minor changes in the absorption spectra, within the same concentration range. However, $\mathrm{Br}^{-}$did not give rise to any such changes. Analysis of the binding affinity of $\mathbf{1}$ for the above interactions showed that pyrophosphate was detected most strongly. However, and most importantly, these changes were not reversed upon the addition of competitive hydrogen bonding solvents such as $\mathrm{H}_{2} \mathrm{O}$ or $\mathrm{MeOH}$, strongly indicating that the ions could be detected in a mixture of organic-aqueous solution. ${ }^{11 b}$

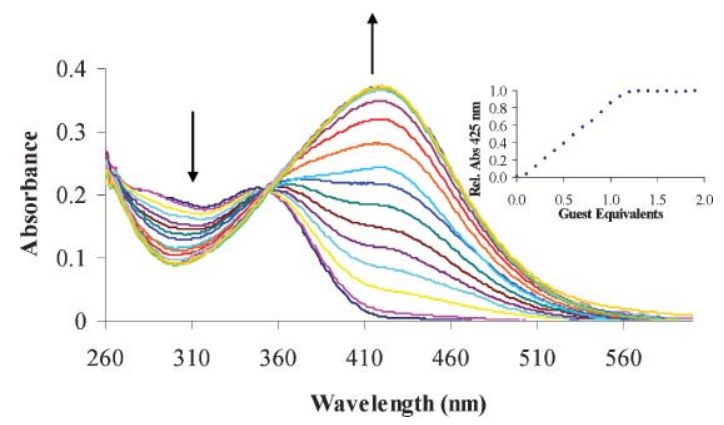

Fig. 2 The changes in the UV-Visible spectra of 1 upon addition of $\mathrm{HP}_{2} \mathrm{O}_{7}{ }^{3-}(0 \rightarrow 2$ equivalents $)$ in DMSO at room temperature.

With this information in hand, we set out to determine the sensing ability of 1 towards biological phosphate based anions such $\mathrm{H}_{2} \mathrm{PO}_{4}{ }^{-}, \mathrm{HP}_{2} \mathrm{O}_{7}{ }^{3-}$, ATP, ADP and AMP, as well as evaluating the response to $\mathrm{AcO}^{-}$and halide in the more competitive 4: 1 DMSO$\mathrm{H}_{2} \mathrm{O}$ solution, where possible deprotonation phenomena, ${ }^{14}$ often associated with anion recognition in organic media, could be minimized. ${ }^{10,11,15}$ These titrations were carried out using both TBA and $\mathrm{Na}^{+}$salts of these anions. The changes in the absorption spectra of 1 in 4 : 1 DMSO- $\mathrm{H}_{2} \mathrm{O}$ upon titration with $\mathrm{H}_{2} \mathrm{PO}_{4}^{-}$ are shown in Fig. 3. Under these solvent conditions, 1 displayed similar changes in the absorption spectra as shown above, with a $\lambda_{\max }$ of $344 \mathrm{~nm}$ which was shifted to a longer wavelength, $\lambda_{\max }=412 \mathrm{~nm}$ upon recognition of the anion. While again, no 'clear' isosbestic point was observed for these changes, a 'pseudo' isosbestic point can be seen at ca. $340 \mathrm{~nm} \cdot{ }^{15-17}$ The absorption changes observed at $425 \mathrm{~nm}$ are shown as an inset in Fig. 3,

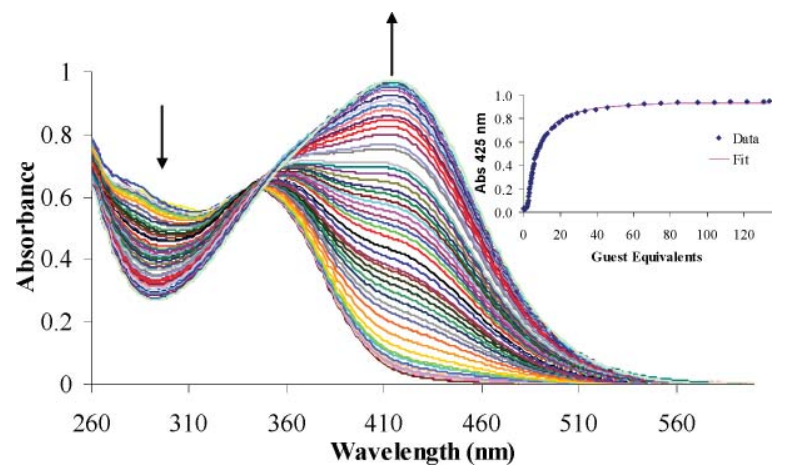

Fig. 3 The changes in the UV-Visible spectra of 1 upon addition of $\mathrm{H}_{2} \mathrm{PO}_{4}^{-}(0 \rightarrow 133$ equivalents $) 4: 1$ DMSO- $\mathrm{H}_{2} \mathrm{O}$ solution at room temperature. Inset: the observed changes at $425 \mathrm{~nm}$ and the result (solid line) of the fitted data using the SPECFIT programme.

and demonstrate the presence of some possible aggregation effect (shown more clearly in the ESI, Fig. S7 $\$$ ) at the start of the titration. The titration of $\mathrm{HP}_{2} \mathrm{O}_{7}{ }^{3-}$, AMP and ADP also gave rise to the formation of a new band at long wavelengths (see ESI, Fig. S6\$), while no significant changes were seen in the absorption spectra upon titration with ATP. Hence, 1 showed a strict selectivity for both AMP and ADP over ATP. Once again, these changes were visible to the naked eye, and indicate a common mechanism for the binding of these anions, most likely occurring within the cleft of the sensor, through hydrogen bonding interactions. The changes seen for all of these $\mathrm{Na}^{+}$salts, at $425 \mathrm{~nm}$ are shown in Fig. 4.

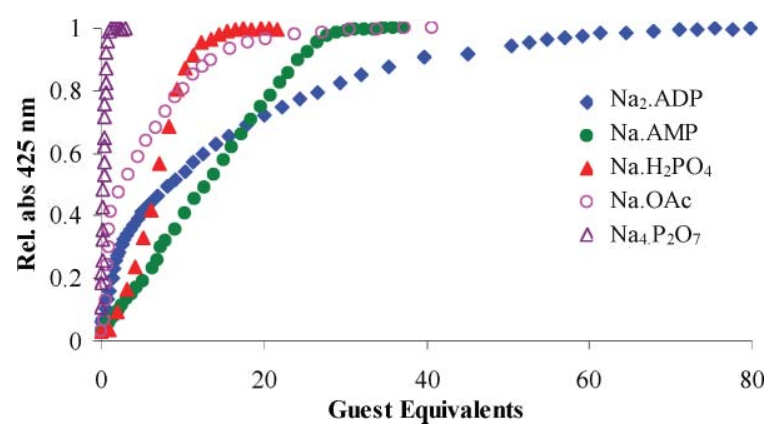

Fig. 4 The changes in the UV-Visible spectra of $1\left(3 \times 10^{-5} \mathrm{M}\right)$ at $425 \mathrm{~nm}$ upon addition of various anions in $4: 1 \mathrm{DMSO}-\mathrm{H}_{2} \mathrm{O}$ solution.

The spectral changes observed in the $4: 1$ DMSO- $\mathrm{H}_{2} \mathrm{O}$ solution were analysed using the non linear regression analysis program SPECFIT. The fitting of the data observed for TBA. $\mathrm{H}_{2} \mathrm{PO}_{4}$ is shown as an inset in Fig. 3, and demonstrates excellent correlation between the experimental and the theoretical fit. From this fitting, both the affinity constants $(\log \beta$ or $\log K)$ and the speciation distribution in solution could be estimated. On all occasions, the changes were fitted to various combinations of stoichiometries, including $1: 1,1: 2$ and $1: 3$ host-guest species. For $\mathrm{H}_{2} \mathrm{PO}_{4}{ }^{-}$, both $1: 1$ and $1: 2$ binding were observed, with a $\log \beta$ of 4.24 and 8.31 , respectively. The binding constants obtained for the $\mathrm{HP}_{2} \mathrm{O}_{7}{ }^{3-}$ titration showed, however, a very clear and stable $1: 1$ species in solution with a $\log K_{1: 1}=6.53$, Fig. 5 . This is a very high affinity, particularly given the fact that the interaction of the anion with $\mathbf{1}$ is expected to be through hydrogen bonding interactions to the amidothiourea moieties, possibly in a manner such that 


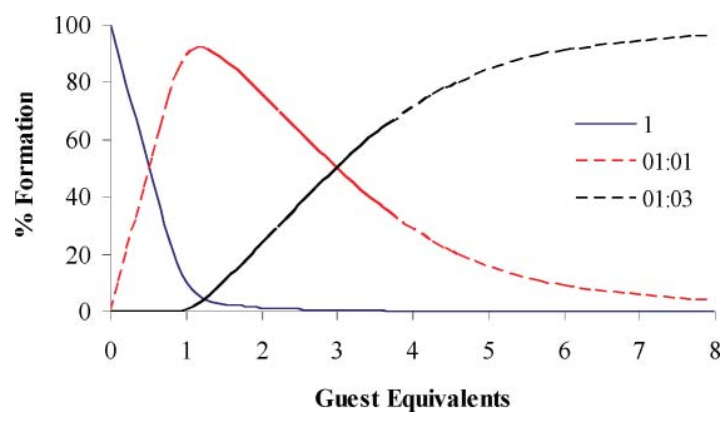

Fig. 5 The speciation distribution diagram for $1\left(3 \times 10^{-5} \mathrm{M}\right)$ upon titration with $\mathrm{HP}_{2} \mathrm{O}_{7}{ }^{3-}$ in $4: 1 \mathrm{DMSO}-\mathrm{H}_{2} \mathrm{O}$ solution. $\mathrm{Blue}=\mathbf{1}$; red $=$ $1: 1$ formation and black $=1: 3$ (host-guest). The presence of a $1: 2$ stoichiometry was, interestingly, not observed in a high percentage yield. The $1: 3$ species most likely represents the deprotonated receptor.

the anion bridges the two amidothiourea moieties within the cleft of the sensor. Analysis of the results obtained from the fitting of ADP, using SPECFIT, also indicated the formation of different absorbing species in solution. However, while the fitting of these results gave good correlation with the experimental data, it only resulted in binding constants that carried unacceptably high errors. Nevertheless, we can conclude from these analyses that the $1: 1$ stoichiometry was initially formed as the main dominant species in solution, and that at higher concentrations of the ion, other hostguest complexes were also formed. The results from the fittings in aqueous solution are summarised in Table 1 .

While the above results indicated the generation of new hostguest complexes in solution, that are formed through hydrogen bonding between the amidothioureas and the anions, it cannot be ruled out that such binding will eventually lead to deprotonation by the anions. ${ }^{14}$ Furthermore, it is also possible that both mechanisms are operating in concert. The binding trend seen above seems to suggest that such combined processes might be operating, and that the balance between hydrogen bonding $v s$. deprotonation is being tilted during the recognition process. Consequently, sensor 1 was also titrated with $\mathrm{NaOH}$ in order to directly deprotonate the receptor in the $4: 1 \mathrm{DMSO}-\mathrm{H}_{2} \mathrm{O}$ solution. This titration indeed confirmed the $\mathrm{HO}^{-}$induced deprotonation in the absorption spectra. However, the titration profile was somewhat different to that observed for the other anions (see ESIt). Hence, with the aim of further investigating the balance between hydrogen bonding and

Table 1 Stability constants obtained from fitting the changes in the absorption spectra of $\mathbf{1}$ using the nonlinear regression analysis program SPECFIT $^{a, b}$

\begin{tabular}{lcclc}
\hline Anions & $\mathrm{H}-\mathrm{G}$ & $\log \beta$ & Standard deviation & $\log K$ \\
\hline TBA.OAc & $1: 1$ & 5.73 & \pm 0.18 & - \\
& $1: 2$ & 11.3 & \pm 0.13 & 5.57 \\
TBA. $\mathrm{H}_{2} \mathrm{PO}_{4}$ & $1: 1$ & 4.24 & \pm 0.06 & - \\
TBA. $\mathrm{HP}_{2} \mathrm{O}_{7}{ }^{3}$ & $1: 2$ & 8.31 & \pm 0.04 & - \\
& $1: 1$ & 6.53 & \pm 0.20 & - \\
& $1: 2$ & - & - & - \\
ADP. $\mathrm{Na}_{2}$ & $1: 3$ & 15.5 & \pm 0.20 & - \\
& $1: 1$ & 3.17 & \pm 0.10 & 3.77 \\
& $1: 2$ & 6.94 & \pm 0.10 & 3.42
\end{tabular}

${ }^{a}$ All measured in $4: 1$ DMSO- $\mathrm{H}_{2} \mathrm{O}$ solution. ${ }^{b}$ The binding profile for $\mathrm{F}^{-}$ and AMP.Na were too complicated to accurately determine $\log \beta$. deprotonation for the anion recognition of sensor $\mathbf{1}$, we titrated $\mathbf{1}$, with TBA. $\mathrm{H}_{2} \mathrm{PO}_{4}, \mathrm{NaAMP}$, TBA.F and $\mathrm{NaOH}$ in DMSO- $d_{6}$ using ${ }^{1} \mathrm{H}$ NMR spectroscopy. ${ }^{2,18}$ The results obtained for the titration of TBA. $\mathrm{H}_{2} \mathrm{PO}_{4}$, are shown in Fig. 6.

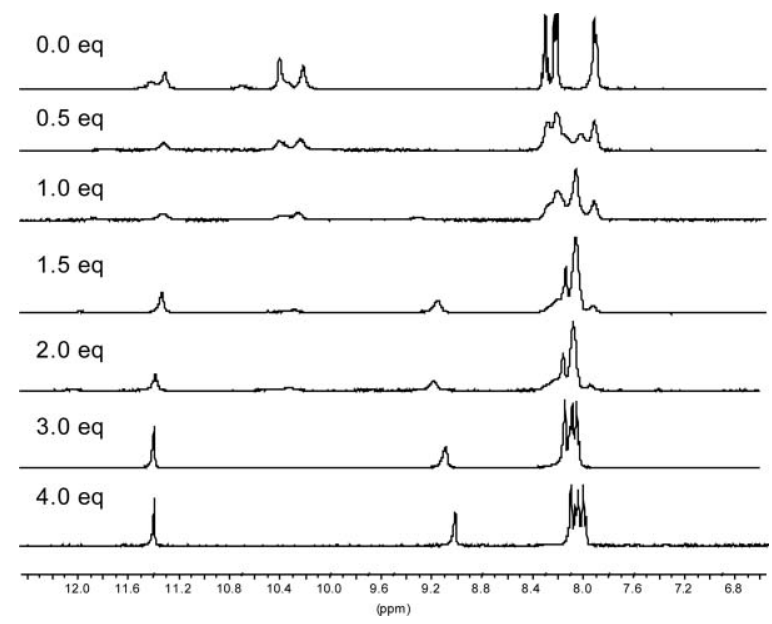

Fig. 6 The ${ }^{1} \mathrm{H}$ NMR $(400 \mathrm{MHz})$ titration of $1(9.5 \mathrm{mM})$ with $\mathrm{H}_{2} \mathrm{PO}_{4}{ }^{-}$in DMSO- $d_{6}$.

In general, these titrations gave rise to changes in the chemical shift of both the aryl and the $\mathrm{N}-\mathrm{H}$ protons. However, even though the ${ }^{1} \mathrm{H}$ NMR showed similar features at each of the endpoints, there were distinguishable differences, particularly for the aryl resonances, for these titrations (see ESIt). The changes seen in Fig. 6 give an indication of the general trend observed for these titrations, where the endpoint of each titration produced a spectrum in which there were only two identifiable NH resonances, which integrate for four protons. These resonances were sharp and clearly indicative of the formation of a new species, which was structurally different from that seen for $\mathbf{1}$. This we assign to hostguest formation, which potentially involves the deprotonation of two $\mathrm{N}-\mathrm{H}$ donors, rather then broadening of these signals. Selective ROESY NMR experiments on 1 ( $600 \mathrm{MHz}, \mathrm{DMSO}-d_{6}$ ) after the addition of 2.5 eq of TBAF suggest that the deprotonated $\mathrm{N}-$ $\mathrm{H}$ moieties are the thiourea protons adjacent to the amido $\mathrm{N}-$ $\mathrm{H}$ moieties (see ESI). Similar deprotonation patterns have been demonstrated by Gale et al. $^{7 b}$

It is worth mentioning that the number of equivalents required to reach the endpoint are in close agreement with those obtained for the absorption titrations carried out in DMSO. Unfortunately, accurate binding constants could not be obtained from these changes. However, these results clearly demonstrate the fine balance between hydrogen bonding and deprotonation in hydrogen bonding anion receptor chemistry, even when carried out in mixed organic-aqueous solution.

In summary, we have developed a new colorimetric anion sensor incorporating two amidothiourea moieties, and demonstrated the sensing of various anions such as biologically relevant phosphates in $4: 1 \mathrm{DMSO}-\mathrm{H}_{2} \mathrm{O}$ solution. The nature of the anion receptor interaction has been defined by absorption and NMR spectroscopy, and we have demonstrated that in the case of $\mathbf{1}$, both hydrogen bonding and deprotonation interactions are most likely involved in the recognition process. We are currently exploring the sensing 
ability of structures related to $\mathbf{1}$, possessing more water soluble functional groups, in greater detail.

\section{Acknowledgements}

We would also like to thank the SFI, CSCB and Trinity College Dublin for financial support. We would like to thank Dr Dilip Rai, CSCB, UCD for MS analysis and Dr Brendan Twamley for his help with resolving the X-ray structure of $\mathbf{1}$.

\section{Notes and references}

$\S$ Synthesis of 1,6-bis-[4-nitrophenyl (thioureidocarbamoyl)]-pyridine (1). 2,6-Pyridinedicarboxylic acid, dihydrazide $(0.281 \mathrm{~g}, 1.03 \mathrm{mmol}, 1 \mathrm{eq})$ and 4-nitrophenylisothiocyanate $(0.518 \mathrm{~g}, 2.88 \mathrm{mmol}, 2 \mathrm{eq})$ were refluxed in acetonitrile for $16 \mathrm{~h}$. The precipitate was isolated by suction filtration and washed with acetonitrile to give a pale yellow solid, $0.784 \mathrm{~g}, 98 \%$. Mp 203$205^{\circ} \mathrm{C} ; \delta_{\mathrm{H}}\left(600 \mathrm{MHz}, \mathrm{DMSO}-d_{6}\right): 11.30\left(2 \mathrm{H}\right.$, br s, $\left.\mathrm{N} H \mathrm{NH}_{\text {urea }}\right), 10.37(2 \mathrm{H}$, br s, NHN $\left.H_{\text {urea }}\right), 10.20\left(2 \mathrm{H}\right.$, br s, N $\left.H_{\text {urea }}\right), 8.31(2 \mathrm{H}$, br s, $\mathrm{CH}$ py $), 8.30(1 \mathrm{H}$, br s, CHpy), $8.22\left(4 \mathrm{H}\right.$, br s, $\left.\mathrm{CHCNO}_{2}\right), 7.92(4 \mathrm{H}$, br s, $\mathrm{Hz}, \mathrm{C} H \mathrm{CNH}$ ); $\delta_{\mathrm{C}}\left(150 \mathrm{MHz}\right.$ DMSO- $\left.d_{6}\right) 181.1(\mathrm{C}=\mathrm{S}), 162.8(\mathrm{C}=\mathrm{O}), 147.8(C 6), 145.7$ $(C \mathrm{NH}), 143.6\left(\mathrm{CNO}_{2}\right), 139.8(\mathrm{C} 3 / 5), 125.6(C 4), 125.2(\mathrm{CHCNH}), 123.9$ $\left(C \mathrm{HCNO}_{2}\right) ; \delta_{\mathrm{N}}\left(600 \mathrm{MHz}\right.$ DMSO- $\left.d_{6}\right) 129.6\left(\mathrm{~N}_{\text {amido }}\right), 127.7\left(\mathrm{NH}_{\text {urea }}\right), 126.2$ $(N \mathrm{HNH})$; IR $v_{\max }\left(\mathrm{cm}^{-1}\right) 3128,2962,1704,1597,1549,1506,1469,1345$, 1278, 1219, 1157, 1002, 887, 851, 745, 698. HRMS $\left(\mathrm{ES}^{+}\right)$: calculated for $\mathrm{C}_{21} \mathrm{H}_{18} \mathrm{~N}_{9} \mathrm{O}_{6} \mathrm{~S}_{2}: 556.0821$, found: $556.0822(\mathrm{M}+\mathrm{H})$.

I $X$-Ray crystallographic information. The data were collected on a Rigaku Saturn 724 CCD diffractomer. A crystal, of dimensions $0.27 \times 0.20 \times$ $0.08 \mathrm{~mm}$, was selected and mounted on a $0.30 \mathrm{~mm}$ quartz fibre tip and immediately placed on the goniometer head in a $123 \mathrm{~K} \mathrm{~N}_{2}$ gas stream. The data set was collected using Crystalclear-SM 1.4.0 software and 1680 diffraction images of $0.5^{\circ}$ per image were recorded. Data integration, reduction, corrections for absorption and polarization effects were all performed using Crystalclear-SM 1.4.0 software. Space group determination, structure solution and refinement were obtained using Crystalstructure ver. 3.8 and Shelxt ${ }^{19}$ ver. 6.14 software. Crystal data: $\mathrm{C}_{27} \mathrm{H}_{35} \mathrm{~N}_{9} \mathrm{O}_{9} \mathrm{~S}_{5}, M=789.99$, triclinic, $a=14.489(3), b=15.929(5), c=$ $17.154(5) \AA, \alpha=87.377(7)^{\circ}, \beta=68.142(6)^{\circ}, \gamma=81.774(8)^{\circ}, U=$ $3636.5(17) \AA^{3}, T=123 \mathrm{~K}$, space group $P \overline{1}, Z=4, \mu(\mathrm{Mo}-\mathrm{K} \alpha)=$ $0.381 \mathrm{~mm}^{-1}, 36636$ reflections collected, 12589 unique, $\left(R_{\text {int }}=0.0430\right)$, $R=0.0815, w R 2[I>2 \sigma(I)]=0.2394$. CCDC deposition number 649247 .

1 J. L. Sessler, P. A. Gale and W. S. Cho, Anion Receptor Chemistry, Royal Society of Chemistry, Cambridge, UK, 2006.

2 T. Gunnlaugsson, M. Glynn, G. M. Tocci (née Hussey), P. E. Kruger and F. M. Pfeffer, Coord. Chem. Rev., 2006, 250, 3094.

3 (a) P. A. Gale, Acc. Chem. Res., 2006, 39, 465; (b) P. A. Gale and R. Quesada, Coord. Chem. Rev., 2006, 250, 3219; (c) P. Padros and R. Quesada, Supramol. Chem., 2008, 20, 201; (d) J. W. Steed, Chem. Commun., 2006, 2637; (e) E. A. Katayev, Y. A. Ustynyuk and J. L. Sessler, Coord. Chem. Rev., 2006, 250, 3004; (f) S. O. Kang, Md. A. Hossain and K. Bowman-James, Coord. Chem. Rev., 2006, 250, 3038; (g) T. Gunnlaugsson, H. D. P. Ali, M. Glynn, P. E. Kruger, G. M. Hussey, F. M. Pfeffer, C. M. G. dos Santos and J. Tierney, J. Fluoresc., 2005, 15, 287; (h) R. Martínez-Máñez and F. Sancenón, Chem. Rev., $2003, \mathbf{1 0 3}, 4419$.

4 (a) C. M. G. dos Santos and T. Gunnlaugsson, Tetrahedron Lett., 2007, 48, 3135; (b) R. M. Duke and T. Gunnlaugsson, Tetrahedron, 2007, 48, 8043; (c) A. P. Davis, J. E. O'Brien and M. Glynn, Org. Biomol. Chem., 2005, 3, 48; (d) T. Gunnlaugsson, A. P. Davis, J. E. O'Brien and M. Glynn, Org. Lett., 2002, 4, 2449; (e) T. Gunnlaugsson, A. P. Davis and M. Glynn, Chem. Commun., 2001, 2556.

5 (a) A. J. Lowe, G. A. Dyson and F. M. Pfeffer, Eur. J. Org. Chem., 2008, 1559; (b) F. M. Pfeffer, M. Seter, N. Lewcenko and N. W. Barnett, Tetrahedron Lett., 2006, 47, 5251; (c) P. D. Beer, M. R. Sambrook and D. Curiel, Chem. Commun., 2006, 2105; (d) F. Y. Wu, Z. Li, L. Guo, X. Wang, M. H. Lin, Y. F. Zhao and Y. B. Jiang, Org. Biomol. Chem., 2006, 4, 624; (e) K. Ghosh and S. Adhikari, Tetrahedron Lett., 2006, 47, 8165; (f) Y. Li, L. F. Cao and H. J. Tian, J. Org. Chem., 2006, 71, 8279; (g) D. Esteban-Gomez, L. Fabbrizzi and M. Liechelli, J. Org. Chem., 2005, 70, 5717; (h) M. Tomasulo and F. M. Raymo, Org. Lett., 2005, 7, 4633.

6 (a) J. Massue, S. J. Quinn and T. Gunnlaugsson, J. Am. Chem. Soc., 2008, 130(22), 6900-6901; (b) S. E. Plush and T. Gunnlaugsson, Org. Lett., 2007, 9, 1919; (c) H. N. Lee, K. M. K. Swamy, S. K. Kim, J.-Y. Kwon, Y. Kim, S.-J. Kim, Y.-J. Yoon and Y. Yoon, Org. Lett., 2007, 9, 243; (d) J. P. Leonard, C. M. G. dos Santos, S. E. Plush, T. McCabe and T. Gunnlaugsson, Chem. Commun., 2007, 129; (e) E. J. O'Neil and B. D. Smith, Coord. Chem. Rev., 2006, 250, 3068; $(f)$ B. T. Nguyen and E. V. Anslyn, Coord. Chem. Rev., 2006, 250, 3118; (g) A. J. Harte, P. Jensen, S. E. Plush, P. E. Kruger and T. Gunnlaugsson, Inorg. Chem., 2006, 45, 9465; (h) T. Gunnlaugsson and J. P. Leonard, Chem. Commun., 2005, 3114.

7 (a) G. W. Bates, P. A. Gale and M. E. Light, Chem. Commun., 2007, 2121; (b) L. S. Evans, P. A. Gale, M. E. Light and R. Quesada, Chem. Commun., 2006, 965.

8 K. Kavallieratos, S. R. de Gala, D. J. Austin and R. H. Crabtree, J. Am. Chem. Soc., 1997, 119, 2325.

9 L.-H. Wei, Y.-B. He, J.-L. Wu, L.-Z. Meng and X. Yang, Supramol. Chem., 2004, 16, 561 .

10 (a) W.-X. Liu and Y.-B. Jiang, Org. Biomol. Chem., 2007, 5, 1771; (b) E. Quinlan, S. E. Matthews and T. Gunnlaugsson, J. Org. Chem., 2007, 72, 7497; (c) E. Quinlan, S. E. Matthews and T. Gunnlaugsson, Tetrahedron Lett., 2006, 47, 9333.

11 (a) H. D. P. Ali, P. E. Kruger and T. Gunnlaugsson, New J. Chem., 2008, 32, 1153-1161; (b) T. Gunnlaugsson, P. E. Kruger, P. Jensen, J. Tierney, H. D. P. Ali and G. M. Hussey, J. Org. Chem., 2005, 70, 10875.

12 (a) F. M. Pfeffer, P. E. Kruger and T. Gunnlaugsson, Org. Biomol. Chem., 2007, 5, 1894; (b) F. M. Pfeffer, T. Gunnlaugsson, P. Jensen and P. E. Kruger, Org. Lett., 2005, 7, 5357.

13 Other recent examples include: (a) K. M. K. Swamy, S. K. Kwon, H. N. Lee, S. M. S. Kumar, J. S. Kim and J. Yoon, Tetrahedron Lett., 2007, 48, 8683; (b) Z. Xu, S. Kim, H. N. Kim, S. J. Han, C. Lee, J. S. Kim, X. Qian and J. Yoon, Tetrahedron Lett., 2007, 48, 9151; (c) H. Wang and W.-H. Chan, Org. Biomol. Chem., 2008, 6, 162; (d) K. S. Moon, N. Singh, G. W. Lee and D. O. Jang, Tetrahedron, 2007, 63, 9106; (e) H. M. Chawla and S. P. Singh, Tetrahedron, 2008, 64, 741; (f) M. Kumar, J. N. Babu, V. Bhalla and N. S. Athwal, Supramol. Chem., 2007, 19, 511; (g) D. Saravankumar, S. Deveraj, S. Iyyampillai, K. Mohandoss and M. Kandaswamy, Tetrahedron Lett., 2008, 49, 127; (h) C. Liu, X. Qian, J. Wang and Z. Li, Tetrahedron Lett., 2008, 49, 1087; (i) R. Nishiyabu and P. Anzenbacher, Jr., J. Am. Chem. Soc., 2005, 127, 8270.

14 (a) C. Perez-Casas and A. K. Yatsimirsky, J. Org. Chem., 2008, 73, 2275; (b) T. Gunnlaugsson, P. E. Kruger, T. C. Lee, R. Parkesh, F. M. Pfeffer and G. M. Hussey, Tetrahedron Lett., 2003, 44, 6575; (c) T. Gunnlaugsson, P. E. Kruger, P. Jensen, F. M. Pfeffer and G. M. Hussey, Tetrahedron Lett., 2003, 44, 8909; (d) S. Camiolo, P. A. Gale, M. B. Hursthouse and M. E. Light, Org. Biomol. Chem., 2003, 1, 741; (e) D. E. Gómez, L. Fabbrizzi, M. Licchelli and E. Monzani, Org. Biomol. Chem., 2005, 3, 1495.

15 Due to lack of solubility of $\mathbf{1}$ in pure $\mathrm{H}_{2} \mathrm{O}$, we had to use the mixed solvent system. We are currently working on other derivatives of $\mathbf{1}$ with the aim of obtaining fully $\mathrm{H}_{2} \mathrm{O}$ soluble sensors.

16 Due to the presence of $\mathrm{H}_{2} \mathrm{O}$ in solution, these titrations required higher concentrations of anion in order for the plateau to be reached. Titrations of 1 using $\mathrm{H}_{2} \mathrm{PO}_{4}{ }^{-}$and pyrophosphate were also carried out at two different concentrations: $1 \times 10^{-5} \mathrm{M}$ and $3 \times 10^{-5} \mathrm{M}$, respectively. The changes in the absorption spectra of 1 were identical. Nevertheless, no significant changes were seen in the absorption spectra until after the addition of one and two equivalents of these anions, respectively. We believe that this is possibly due to complexed kinetics, or that some aggregation phenomenon is initially occurring. We are currently in the process of elucidating this phenomenon.

17 It is also worth pointing out that the ratio between the absorption maxima at 344 and $412 \mathrm{~nm}$, respectively (Fig. 3), is less than that observed in pure DMSO solution (Fig. 2).

18 (a) T. Gunnlaugsson, A. P. Davis, J. E. O'Brien and M. Glynn, Org. Biomol. Chem., 2005, 3, 48; (b) T. Gunnlaugsson, A. P. Davis, G. M. Hussey, J. Tierney and M. Glynn, Org. Biomol. Chem., 2004, 2, 1856.

19 SMART Software Reference Manual, version 5.625, Bruker Analytical X-Ray Systems Inc., Madison, WI, 2001, G. M. Sheldrick, SHELXTL. 